\title{
UNLOCKING THE SECRET OF E-LOYALTY: A STUDY FROM TIKTOK USERS IN CHINA
}

\author{
Donny Susilo \\ Department of Business Administration, Asia University, Taiwan \\ Donnysusilo777@gmail.com
}

\begin{abstract}
TikTok is a recent global phenomenon and in the first quarter of 2020 alone it has TikTok been downloaded 315 million times. People love it because it allows them to spur creativity in video content and increase their online presence. Founded by a Chinese company, this social networking application has become a trend for about 400 million loyal users in China. However, studies about how people become loyal to TikTok are lacking. This study aims to examine the effect of service quality and satisfaction to loyalty of TikTok users in China. Since the study was focused in an online environment, the terms E-service quality, E-satisfaction and E-loyalty are used instead of the conventional ones. SEM-PLS was employed to analyze valid and reliable data which was successfully collected from 400 Chinese TikTok users. The result confirmed that E-service quality affects significantly and positively E-satisfaction and E-loyalty, E-satisfaction also significantly and positively affects E-loyalty and E-satisfaction mediates the relationship between E-service quality and E-loyalty. Since the TikTok application is easy to use with interesting features for its users, the company has successfully delivered information about the booming of TikTok use all over the world and impressing users so that they have high trust in the application's ability to make them more famous and socially famous. Therefore users believe that TikTok can provide them something better than what they expected. When reality exceeds the expectation, customers will be satisfied. TikTok is also believed to have a good, reliable and available system.
\end{abstract}

Keywords: E-Service Quality, E-Satisfaction, E-Loyalty

Copyright (C) 2020, International Journal of Economics, Business and Entrepreneurship | IJEBE | FEB-UNILA

\section{INTRODUCTION}

Technology and the internet have experienced rapid progress, as evidenced by the majority of people in the world having smartphones or using of the Internet. In daily activities, Internet usage includes social networking, transportation, shopping, culinary and other services. The rapid use of the internet for various needs creates many business opportunities that can be utilized to generate income. One of the most opportune and successful companies is BhyteDance with its new phenomenal mobile application TikTok. TikTok (Dǒuyin in Chinese) is a Chinese video-sharing social networking service owned by ByteDance, a Beijing-based Internet technology company 
founded in 2012 by Zhang Yiming. It is used to create short dancing, lip-syncing, comedy and talent videos. ByteDance first launched Douyin for the Chinese market in September 2016. In 2017, TikTok was launched for iOS and Android in most markets outside of China. TikTok is a worldwide phenomenon today, but relevant research related to TikTok is still lacking. Therefore, the author initiated this research to figure out how TikTok users become loyal to the mobile application. Singh (2020) stated that TikTok's achieved a new record in only five months after reaching 1.5 billion downloads. In the first quarter of 2020 alone TikTok has been downloaded 315 million times.

Figure 1. TikTok Global Downloads by Quarter

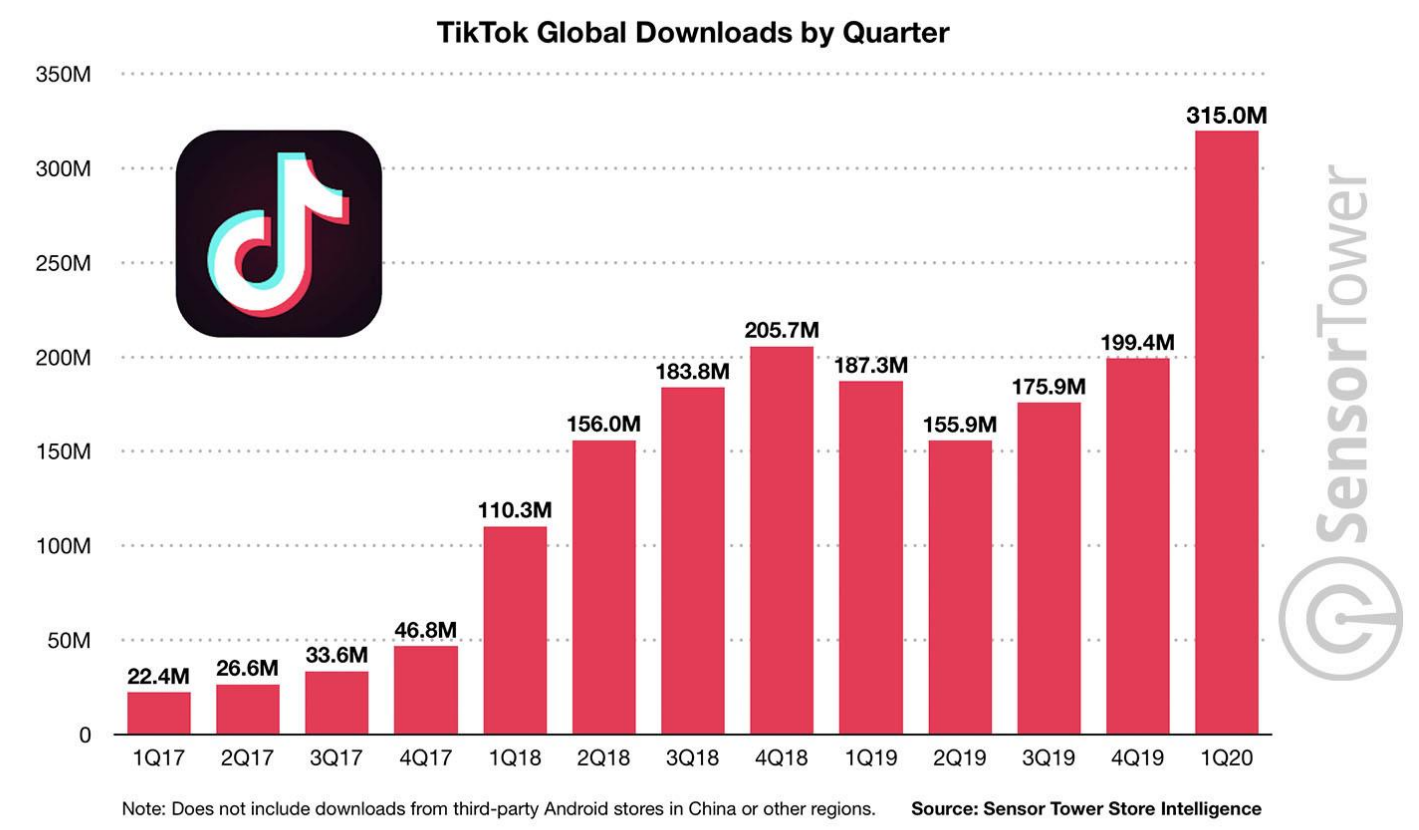

(P) SensorTower Data That Drives App Growth

sensortower.com

Source: Sensor Tower (2020)

Sensor Tower said the recent popularity of TikTok was driven by the Corona virus pandemic, which made many people want to try out new applications. The country which is the biggest market for TikTok is India with 30.3\% of total downloads, followed by China (9.7\%) and the United States (8.2\%). This application has been downloaded 611 million times in this South Asian country. The soaring popularity of TikTok has also generated a lot of income. TikTok users have spent USD 456.7 million on the application and the total user base of TikTok in China reached 400 million active users in May 2020 (Singh, 2020). Based on the description of the study gap, this research aims to examine the relationship between service quality, satisfaction and loyalty of online social networking service users. Besides being able to be used as the latest reference in the field of marketing research, other benefits that can be obtained from the results of this research include acting as a reference for companies or businesses in the online social networking service sector to increase the loyalty of their customers through service quality and customer satisfaction.

Research that discusses loyalty of online environment users generally use service quality (Salameh \& Hassan, 2015) as a variable that can determine customer 38 
behaviour, satisfaction, and intention to use certain product or service. It is said that service quality provides long-term success and can be a competitive advantage for a company. Therefore, it is important to assess and measure the quality of services, especially services provided in e-commerce environments (Huang \& Benyoucef, 2015). Bismo, Sarjono, \& Ferian (2018) found that service quality has a positive and significant effect on customer satisfaction and has a positive but insignificant effect on customer loyalty. Research conducted by Aramita et al. (2018) found that not all aspects of quality affect loyalty, that is only tangible, responsive, reliability, and assurance did, whereas empathy only indirectly affects loyalty through consumer satisfaction. Other findings by $\mathrm{Su}$ et al. (2019) showed that perceptions of service quality, engagement and satisfaction were be good predictors of passenger loyalty, while the direct relationship between perceptions of safety and loyalty has not been confirmed. The differences between these results suggest that the relationship model between service quality, satisfaction and loyalty needs to be clarified, especially in the context of online social networking service business.

\section{LITERATURE REVIEW}

\section{E-service quality}

E-service quality is a form of broader service quality for internet media that connects sellers and buyers to fulfil shopping activities effectively and efficiently (Chase et al, 2014). Furthermore, Pratiwi (2016) states that quality e-service will cause customers to feel comfortable and get e-satisfaction in the future, affecting behavioural intention. According to Li \& Suomi (2009), e-service quality can be divided into two dimensions, namely from the perspective of the company and from the perspective of the user. The dimensions of e-service quality from the perspective of the company are: ease of use (ease for customers to use the website), website design (the website must be well designed and visually appealing), reliability (consistency of performance and web reliability), system availability (correct technical functions of the website), privacy (security and protection of customer information), responsiveness (effective handling of problems and returns via the internet), and empathy (individual care and attention given to customers via electronic channels). The dimensions of e-service quality from the customer's perspective are experience (the impression of the company through previous customers) and trust (customer trust by providing fast and information-rich services).

\section{E-satisfaction}

E-satisfaction can be considered as a feeling that is beneficial to customers associated with relationships with the company. E-satisfaction is defined as fulfilling customer pleasure about online experiences (including browsing experience and purchasing experience) with a given e-commerce site. In the context of e-commerce, satisfaction is defined as the satisfaction customers feel with respect to their purchasing experience with the e-commerce provided by the company (Wilson \& Christella, 2019). The creation of customer satisfaction can provide several benefits, including the 
creation of customer loyalty to a particular product and word of mouth recommendations that are profitable for the company.

\section{E-loyalty}

According to Lin, Chiu, Liu, Chen \& Hsiao (2018), E-loyalty is the intention of consumers to re-visit an online shop, which means the interest of consumers towards companies that have the potential to make repeat purchases. According to Asih and Pratomo (2018) e-loyalty is a very interesting thing in the world of virtual commerce because every consumer is able to easily choose the right online store and the best price. In the electronic commerce system, business people must be able to attract the hearts of consumers to be loyal to their online business. When a company has received e-loyalty from customers then maintaining loyalty is a must, because if customers are loyal then they will buy more, are less sensitive to price changes, and their conversation tends to benefit companies or online stores. Customer loyalty can be determined from the behaviour of consumers who always buy regularly or always make repeat purchases. Companies need customer loyalty because without loyalty, the company will not be able to develop properly. Sreeram, Kesharwani \& Desai (2017) said that customers are loyal when they show purchasing behaviour defined by free purchases that are expressed from time to time by some sort of decision-making.

\section{Relationship between e-service quality and e-satisfaction}

The quality of electronic services provided to consumers encourages them to feel satisfied / dissatisfied and is the most dominant factor for this. In the service sector, the quality of electronic services will be highly balanced by service users. They will be satisfied if the quality of services provided is getting better (Santika \& Pramudana, 2018). If the quality of service provided is good, satisfaction will be created, but if the company does not provide the best quality of service, customers will feel disappointed and switch to other products. This research is supported by studies by Melinda (2017), Setyawati (2019), Ting et al (2016). Therefore, based on the description above, a hypothesis can be formulated as follows:

H1: e-service quality gives positive, direct and significant effect to e-satisfaction

\section{Relationship between e-service quality and e-loyalty}

E-loyalty is an advantageous attitude towards customers' online business which results in repurchases behaviour. Based on the opinion of the experts above, it can be concluded that loyalty is not only about repurchase behaviour and commitment, but loyalty also arises from the psychological involvement of consumers with the website, resulting in a positive attitude and intention to buy again in the future (Lin et al, 2018). E-service quality has been found to influence trust and to explain the emotional loyalty of website visitors (Kourtesopoulou, Kehagias \& Papaioannou, 2018). Furthermore, they also revealed that e-service quality, which leads to customer satisfaction, will affect the growth of customer loyalty. This is supported by the findings of Megasari (2019), Eservice quality has a positive and significant effect on e-loyalty. Therefore, based on the description above, a hypothesis can be formulated as follows: 
$\mathrm{H} 2$ : e-service quality gives positive, direct and significant effect to e-loyalty

\section{Relationship between e-satisfaction and e-loyalty}

E-Satisfaction is important in market competition as well as forming customer loyalty (Zeglat, Shrafat \& Al-Smadi, 2016). If the online services obtained meet customer expectation then customers will be satisfied, otherwise if obtained online services do not meet customer expectations, then the customer will be looking for the services of another. Furthermore, Zeglat et al. (2016) found that there was a significant and positive correlation between service quality, customer satisfaction and customer loyalty. When customers have good transaction experiences through the quality of service on a website, the level of loyalty will increase. The consequence of a company's good service is that customers will continue in his choice, creating reciprocal altruism, which most refer to as loyalty. These results are in line with research by Melinda (2017) who stated that e-service quality has a positive and significant effect on customer loyalty. She also said that e-service quality gives greater effect to e-loyalty through e-satisfaction. Therefore, based on the description above, two hypotheses can be formulated as follows:

H3: e-satisfaction gives positive, direct and significant effect to e-loyalty

H4: e-satisfaction mediates the effect between e-service quality and e-loyalty

Figure 2. Research Framework

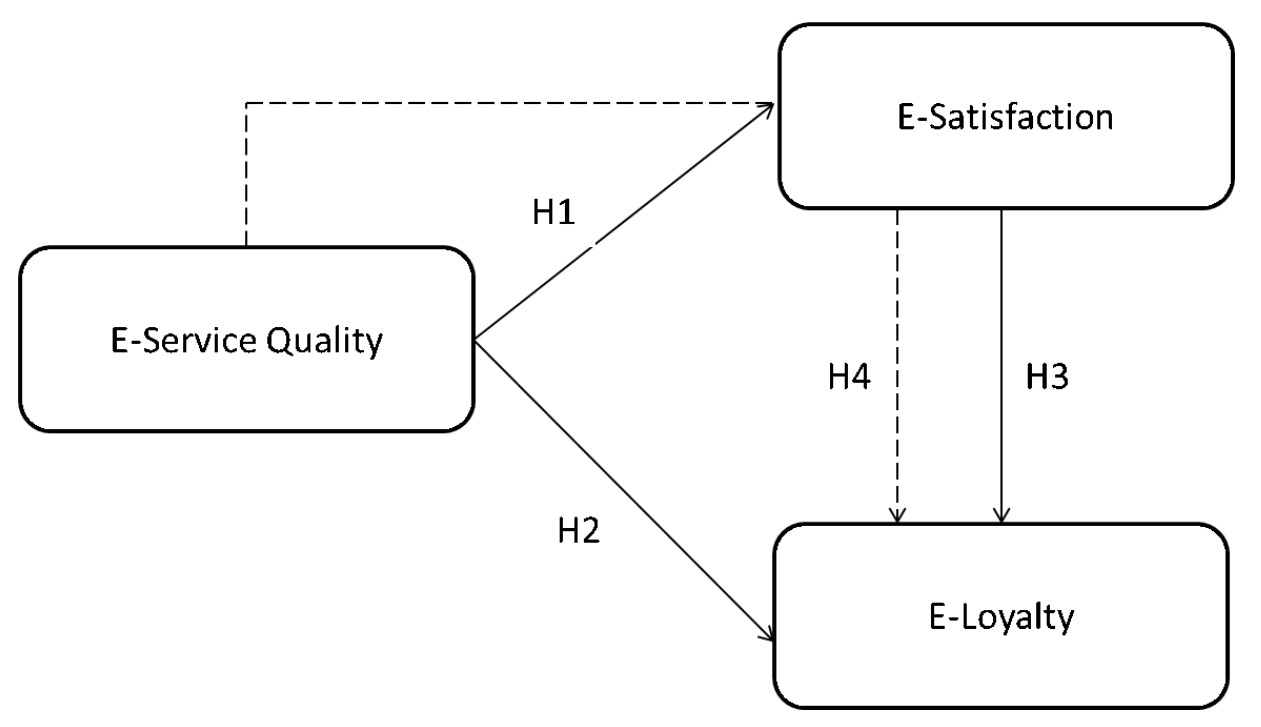

Source: Author (2020)

\section{METHODS}

This study uses quantitative research methods, namely a quantitative study. A survey was used to collect the data. According to Adams \& Lawrence (2018), quantitative research methods are research methods based on the philosophy of positivism, used to examine populations or specific samples. Sampling techniques are 
generally carried out randomly, with data collection using research instruments, and quantitative data analysis or statistics has the aim to test the hypothesis that has been set. The data analysis was done through measurement of model constructs and relationships between variables with the multivariate Structural Equation Modelling (SEM) - Partial Least Square (PLS) technique, which is often referred to as the second generation of multivariate analysis. Validity and reliability analysis was previously done before the hypotheses testing.

A population in social research is defined as a group of people, to whom the research results can be generalized, having shared characteristics that distinguish them from other subject groups (Adams \& Lawrence, 2018). From the above understanding, the population in this study are users of the TikTok application. The sample is part of the number and characteristics possessed by the population. This study uses a nonprobability sampling method with a purposive sampling technique, where samples are taken based on criteria determined by the researcher (Adams \& Lawrence, 2018). The criterion of respondents in this study is all Chinese users who have used TikTok at least two times in their life. The scale used to measure their response is likert scale ranged from 1-6 where 1 = strongly disagree; 2 = disagree; 3 = somewhat disagree; $4=$ somewhat agree; 5 = agree; 6 = strongly agree.

The sample size formula used in this study refers to Slovin (1960). It is computed as $\mathrm{n}=\mathrm{N} /(1+\mathrm{Ne} 2)$.

Whereas:

$\mathrm{n}=$ number of samples

$\mathrm{N}=$ total population

$\mathrm{e}=$ error margin $/$ margin of error

Since the population of TikTok users in China is about 400 million people (Singh, 2020) the suggested number of respondents is 385 people. The questionnaire was translated into the Chinese language and the link was sent to Chinese TikTok users though Chinese social media and online forum. 422 responses were obtained but after removing responses with missing values or were otherwise invalid, 400 valid and reliable responses were secured. Therefore the final number of participating respondents in this study was 400 respondents meaning that the study met the sampling requirement from Slovin. This study used both primary data and secondary data. Primary data is a data source that directly provides data to data collectors. This data was obtained from a questionnaire through survey techniques. Secondary data is a source that does not directly provide data to the data collector. The secondary data were obtained from previous research, government, mass media and reputable statistical releases. Quantitative data collection methods and procedures are carried out through questionnaires (Adams \& Lawrence, 2018).

\section{RESULTS AND DISCUSSION}

\section{Description of Respondent}

Of the 400 valid data obtained and analyzed for this research, most of the data obtained came from Chinese teenagers (17-30 years old), representing $84 \%$ of the total respondents. The rest of the people were above 30 years old. $43 \%$ of the respondents 
were active students in high school and college while $47 \%$ of them were employees. The occupation varies equally from entrepreneurs to employees in private and public companies. More than $80 \%$ of the respondents are heavy users of smartphone and addicted to TikTok because they believe it is good place for them to increase social networking and spur creativity.

\section{Construct Validity}

A construct has to be valid before it was used for further analysis. There were three outer loadings with a value below 0.4 and therefore removed in order to achieve construct validity following Hair, Hult, Ringle \& Sarstedt (2016) which said that the minimum value of outer loading should be 0.4. After removing X6, X11 and X12, Barlett's Test of Sphericity and Kaiser-Meyer-Olkin (KMO) method was performed, this resulted in a KMO value of 0.828 with all outer loadings more than 0.4 , therefore achieving construct validity.

Figure 3. Structural Model Analysis

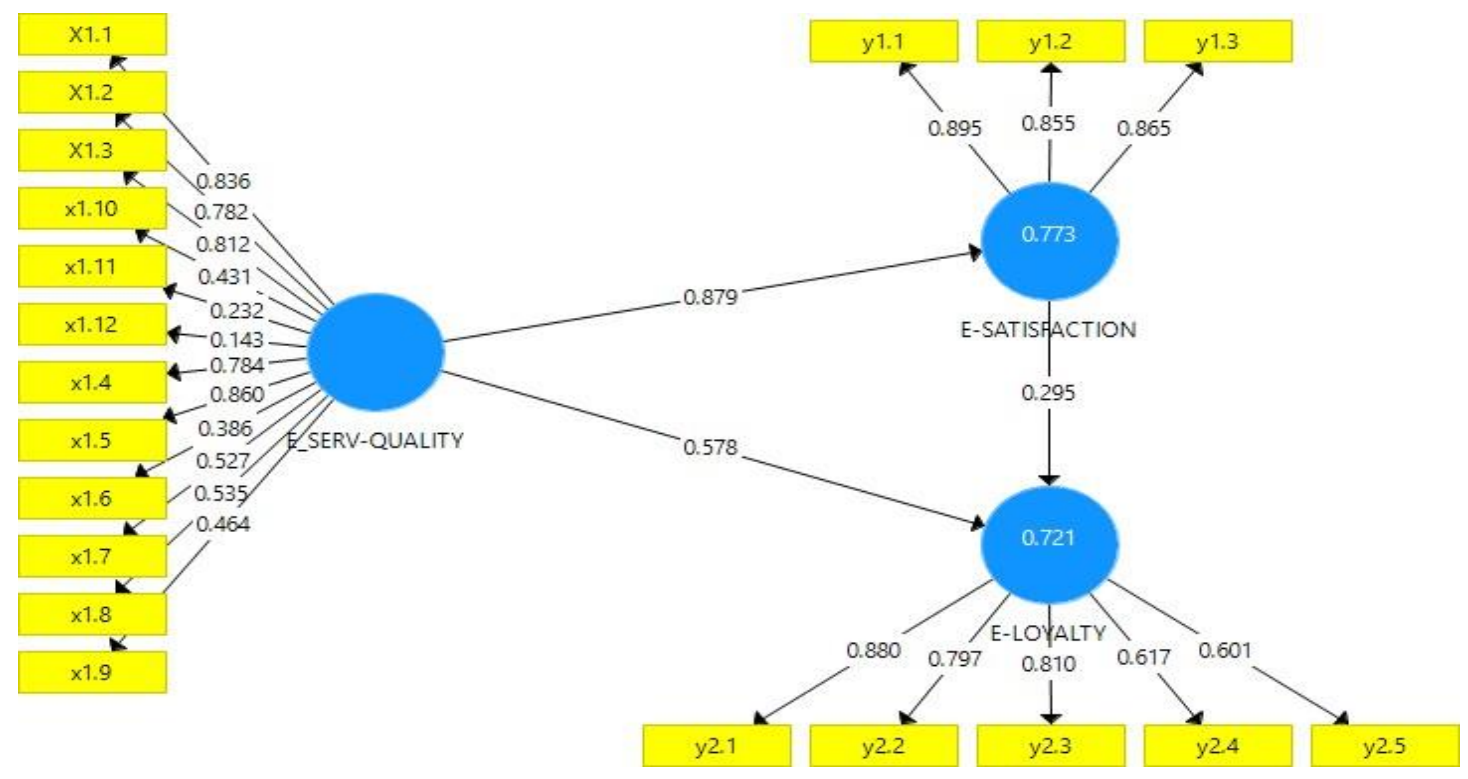

Source: Author Analysis (2020)

\section{Convergent Validity}

Convergent validity can be tested using average variance extracted (AVE). AVE value is used to test the square root of each AVE whether the correlation is greater than each latent construct. If the AVE value of each variable is above 0.5 then it is accepted (Hair et al, 2016), AVE is a criterion indicator validity is measured by convergent validity, in this study all the variables proved to be valid because the AVE value is above 0.5. Outer loadings and Cronbachs Alpha values also showed consistent results because they exceed 0.7 , as recommended by Hair et al (2016). 
Table 1. Construct and Convergent Validity

\begin{tabular}{|c|c|c|c|c|c|}
\hline Constructs & Code & $\begin{array}{c}\begin{array}{c}\text { Outer } \\
\text { Loadings }\end{array} \\
\end{array}$ & AVE & CR & $\begin{array}{c}\text { Cronbachs } \\
\text { Alpha }\end{array}$ \\
\hline \multirow{9}{*}{ E-Service Quality } & $\mathrm{X} 1$ & 0.836 & \multirow{9}{*}{0.54} & \multirow{9}{*}{0.92} & \multirow{9}{*}{0.91} \\
\hline & $\mathrm{X} 2$ & 0.782 & & & \\
\hline & X3 & 0.812 & & & \\
\hline & $\mathrm{X} 4$ & 0.784 & & & \\
\hline & $\mathrm{X} 5$ & 0.860 & & & \\
\hline & $\mathrm{X} 7$ & 0.527 & & & \\
\hline & $\mathrm{X} 8$ & 0.535 & & & \\
\hline & X9 & 0.464 & & & \\
\hline & $\mathrm{X} 10$ & 0.431 & & & \\
\hline \multirow{3}{*}{ E-Satisfaction } & Y11 & 0.895 & \multirow{3}{*}{0.62} & \multirow{3}{*}{0.89} & \multirow{3}{*}{0.84} \\
\hline & Y11 & 0.855 & & & \\
\hline & Y11 & 0.865 & & & \\
\hline \multirow{5}{*}{ E-Loyalty } & Y21 & 0.880 & \multirow{5}{*}{0.64} & \multirow{5}{*}{0.88} & \multirow{5}{*}{0.81} \\
\hline & Y22 & 0.797 & & & \\
\hline & Y23 & 0.810 & & & \\
\hline & Y24 & 0.617 & & & \\
\hline & Y25 & 0.601 & & & \\
\hline
\end{tabular}

Source: Author Analysis (2020)

\section{Discriminant Validity}

Discriminant Validity is a value of cross-loading factors that is useful for knowing if the construct has adequate discrimination by comparing the loading value of the intended construct to the loading value of the other constructs. The loading value of the intended construct must be larger than those of the other constructs. Here it is evident that the construct has adequate discrimination because the value in the diagonal line below is greater than the values below it in the same column. In conclusion the construct has adequate discriminant validity (Hair et al, 2016).

Table 2. Discriminant Validity

\begin{tabular}{|c|c|c|c|c|c|}
\hline \multirow{2}{*}{ Variables } & \multirow{2}{*}{ Mean } & \multirow{2}{*}{ SD } & \multicolumn{3}{|c|}{ Discriminant Validity } \\
\cline { 4 - 6 } & & & E-Service Quality & E-Satisfaction & E-Loyalty \\
\hline E-Service Quality & 4.11 & 0.515 & $\mathbf{0 . 8 5}$ & & \\
\hline E-Satisfaction & 3.98 & 0.404 & 0.53 & $\mathbf{0 . 7 2}$ & \\
\hline E-Loyalty & 4.10 & 0.389 & 0.53 & 0.33 & $\mathbf{0 . 7 4}$ \\
\hline
\end{tabular}

Source: Author Analysis (2020)

\section{Reliability Test}

The Composited Reliability (CR) must be a value above 0.7 to accept this data for processing (Hair et al, 2016). The reliability test is done by looking at the CR value of the indicator block that measures the construct. CR results will show a satisfactory value if above 0.7 . The results in this study (see table 1 ) indicate that all variables have CR values greater than 0.7 so there is no problem in data reliability and the results are consistent. 


\section{Path Analysis}

In PLS, the accuracy of the proposed model can be measured using R-square $\left(\mathrm{R}^{2}\right)$ and Path Coefficient (PC). A structural model test (inner model) is done by taking into account the value of R-square in endogenous latent constructs and t-values for each exogenous latent variable to endogenous latent constructs from bootstrapping results. The inner diagram of the path model in this study is shown in figure 3.

Table 3. Path Analysis

\begin{tabular}{|c|c|c|c|c|c|}
\hline Hypothesis & Path & Coefficient & $\begin{array}{c}\text { Standard } \\
\text { Error }\end{array}$ & P Value & Decision \\
\hline H1 & $\mathrm{X}->$ Y1 & 0.879 & 0.11 & 0.000 & Accepted \\
\hline H2 & $\mathrm{X}->$ Y2 & 0.578 & 0.06 & 0.000 & Accepted \\
\hline H2 & Y1 -> Y2 & 0.295 & 0.08 & 0.001 & Accepted \\
\hline
\end{tabular}

Source: Author Analysis (2020)

Using Partial Least Square (PLS) Analysis, there is an evaluation of the outer and inner models. The validity and reliability is found using the outer model analysis, while analysing the significance of parameters and hypothesis testing uses the inner model. Based on figure 3, it can be seen that the R-square value of E-Loyalty is 0.721 or $72.1 \%$ which means that $72.1 \%$ of the variation in the E-Loyalty variable can be explained by the E-Service Quality and E-satisfaction variables, while the remaining value of $27.9 \%$ is explained by other factors not examined in this study. This value is considered strong because it is above 0.67 . Then the R-square value of E-Satisfaction is 0.773 or $77.3 \%$ which means that $77.3 \%$ of the variation in the E-Satisfaction variable can be explained by E-Service Quality. The remaining value of $22.7 \%$ is explained by other factors not examined in this study. To see whether the independent variable influences or not, that is, to test the hypothesis, one can see the P Value and Path Coefficients that arise from the results of the analysis. When P Value is less than 0.05, hypothesis is accepted and reversely. From the table above, it can be seen that all $\mathrm{P}$ Values are less than 0.05 therefore it can be concluded that all hypotheses are accepted.

\section{E-service quality gives positive, direct and significant effect to e-satisfaction}

The results of the $\mathrm{P}$ value $(0.000<0.05)$ indicates that this study succeeded in proving the second hypothesis which stated that E-Service Quality has a significant positive effect on the E-satisfaction of TikTok users in China. The TikTok application is easy to use, and also has features which interesting to the users. Furthermore the company has successfully delivered information about the booming of TikTok use all over the world and therefore impressing users. They have high trust in the application and think that it can make them more famous and socially famous. Therefore users believe that TikTok can provide them something better than what they expect. When reality exceeds the expectation, customers will be satisfied. TikTok is also believed to have good system, which is reliable and available. Every company must be customercentred; customer satisfaction is the goal and a marketing tool. Today, companies must pay better attention to the level of customer satisfaction, especially for online platform that provide a means for consumers to directly give good and bad comments which can be seen by other customers. To determine the level of customer satisfaction, they need 
to know the level of quality provided by the company in the first place. Satisfaction will arise after a person has good experience with the quality of services provided. The result of this study is also in line with previous researches by Melinda (2017), Setyawati (2019) and Ting et al (2016).

\section{E-service quality gives positive, direct and significant effect to e-loyalty}

The results of the $\mathrm{P}$ value $(0.000<0.05)$ indicates that this study succeeded in proving the first hypothesis which states that E-Service Quality has a significant positive effect on E-Loyalty of TikTok users in China. In a virtual context, e-service quality is an important thing that must be considered and maximized in order to survive and remain the customer's choice. When service quality exceeds customer expectations, it creates high customer loyalty to the company and the service can be categorized as a service that is very high quality or very satisfying. Customers are often not loyal due to poor service. This can damage the company's image and even disrupt corporate profits. TikTok has impressed its users all over the world and the good experience of famous people who use TikTok is well exposed, therefore affecting users to be more loyal to the trending application. Chinese entrepreneurs are great listener, thus they understand how to make their customer loyal (Susilo, 2020). The results of this study support previous researches by Lin et al (2018), Kourtesopoulou, Kehagias \& Papaioannou (2018) and Megasari (2019).

\section{E-satisfaction gives positive, direct and significant effect to e-loyalty}

The results of the $P$ value $(0.001<0.05)$ indicates that this study succeeded in proving the third hypothesis which states that E-Satisfaction has a significant positive effect on E- Loyalty of TikTok users in China. E-satisfaction is a very important determining factor in e-loyalty in the world of buying and selling sites. E- Loyalty is a consumer attitude that brings benefit to the online service provider in form of repeat purchases. E-loyalty is the impact of consumer satisfaction on the quality of online services. Dissatisfied customers will be a threat to the company in the future. Customer satisfaction and customer loyalty are interconnected, which means that if customer satisfaction increases, customer loyalty will also increase and reversely. Hence, in this case customer satisfaction is the cause of customer loyalty. The result of this study is also supported previous research that was conducted by Zeglat et al. (2016) and Melinda (2017).

\section{E-satisfaction mediates the effect between e-service quality and e-loyalty}

As the result of mediation analysis, the relationship between E-service quality and E-loyalty without the mediating variable has an estimated value of 0.578 with a significant $\mathrm{P}$ value where $0.000<0.05$, which means there that there is direct effect without the mediator between positive online experience and e-loyalty. The relationship between E-service quality and E-loyalty with E-satisfaction as mediating variable has estimated value of 0.306 with a significant $P$ value of $0.001<0.05$, which means there that there is direct effect of mediating variable E-satisfaction between E-service quality and E-loyalty. According to the Bairn and Kenny approach, this can be interpreted to have partial mediation. Bootstrapping confirms with a two tailed significance test that it has it has a mediation effect. Loyal customers are those who become profitable assets in the long run for the company, where they continue to buy product or service offered by 
the company, only considering the same brand and not looking for information about other brands. Before the company reaches the customer satisfaction and loyalty stage, the company must pay attention to the quality of their services. Good service quality will create customer satisfaction that will ultimately lead to greater customer loyalty. The result of this study is in line with Melinda (2017) who also stated that E-satisfaction mediates the effect of E-service quality to E-loyalty.

\section{CONCLUSION}

The E-service quality of TikTok has impressed its users in China, creating satisfaction, which leads to loyalty. The quality of its feature and system provides an innovation that allows its users to spend their time for dancing and spurring creativity. The funny content is expected to increase their social presence and even to make them famous and get opportunity in entertainment industry. These cause TikTok to be considered as a useful application by Chinese users. The legitimate information TikTok company provides has convinced its users that it is a good application because it is owned by famous Chinese company. The experiences of famous people and influencers are well exposed, causing the users in China to trust the application as they keep using it, becoming reluctant to switch to a competitor's application. The positive review of TikTok trendiness is also a significant contributor to e-loyalty because it convinces its users about its reliability in enhancing their online presence.

This study is not without limitation. There were no control variables such as age, occupation, gender and level of education employed in this research and only detailed in descriptive analysis. The respondents consisted of new users and heavy users who were not treated differently in this research. Upon completion of this study, companies are recommended to increase their service quality in order to make their customers satisfied and become loyal to their product. The result of this study is also beneficial to the theoretical development of e-loyalty. The future researcher is expected to conduct similar research in other countries, especially western countries that have different cultural values compared to the Chinese. They are also should add more variables in order to understand deeper the factors affecting e-loyalty of TikTok users.

\section{REFERENCES}

Adams, K. A., \& Lawrence, E. K. (2018). Research methods, statistics, and applications. Sage Publications.

Aramita, F., Rini, E. S., \& Sembiring, B. K. F. (2018). The Effect of Service Quality on Satisfaction and Impact on Loyalty User Transportation Service CV Sempati Star Medan-Banda Aceh. In 1st Economics and Business International Conference 2017 (EBIC 2017). Atlantis Press

Asih, R. R. D., \& Pratomo, L. A. (2018). Peran Mediasi E-Satisfaction dan E-Trust terhadap E-Loyalty. Jurnal Manajemen Dan Pemasaran Jasa, 11(1), 125. https://doi.org/10.25105/jmpj.v11i1.2537

Bismo, A., Sarjono, H., \& Ferian, A. (2018). The Effect of Service Quality and Customer Satisfaction on Customer Loyalty: A Study of Grab car Services in Jakarta. Pertanika Journal of Social Sciences \& Humanities 
Chase, R \& Jacobs, R. (2014). Operation and Supply Chain Management. Global Case Edition, New York: Mc Graw Hill

Hair Jr, J. F., Hult, G. T. M., Ringle, C., \& Sarstedt, M. (2016). A primer on partial least squares structural equation modelling (PLS-SEM). Sage publications.

Huang, Z., \& Benyoucef, M. (2015). User preferences of social features on social commerce websites: An empirical study. Technological Forecasting and Social Change, 95, 57-72.

Kourtesopoulou, A., Kehagias, J., \& Papaioannou, A. (2018). Evaluation of E-service quality in the hotel sector: A systematic literature review. In Innovative approaches to tourism and leisure (pp. 173-191). Springer, Cham.

Li, H., \& Suomi, R. (2009). A proposed scale for measuring e-service quality. International Journal of u-and e-Service, Science and Technology, 2(1), 110.

Lin, C. P., Chiu, C. K., Liu, C. M., Chen, K. J., \& Hsiao, C. Y. (2018). Modeling e-loyalty: a moderated-mediation model. The Service Industries Journal,38(15-16), 11601178.

Megasari G.S. (2019). Pengaruh E-Service Quality Terhadap E-Loyality Melalui ESatifaction (Studi Pada Pelanggan Toko Online Shopee di Kota Medan). Jurnal Mantik Penusa Vol. 3, No. 1

Melinda. (2017). Pengaruh E-Service Quality terhadap E-Loyalty Pelanggan Go-jek melalui E-Satisfaction pada Kategori Go-Ride. Jurnal Agora. Vol. 05, No.01

Pratiwi, S. A. (2016). Pengaruh E-Service Quality terhadap Behavior Intentions Dengan E-Satisfaction Sebagai Mediator. Jurnal Computech \& Bisnis, 10(2), 2

Salameh, A. A., \& Hassan, S. B. (2015). Measuring service quality in mcommerce context: A conceptual model. International Journal of Scientific and Research Publications, 5(3), 1-9

Santika, I. W, \& Pramudana, K. A. S. 2018. Peran Mediasi E-Satisfaction pada Pengaruh E-Service Quality terhadap E-Loyalty Situs Online Travel di Bali. INOBIS: Jurnal Inovasi Bisnis dan Manajemen Indonesia. Vol. 01, No. 03

Sensor Tower. (2020). TikTok Crosses 2 Billion Downloads After Best Quarter For Any App Ever. Retrieved from https://sensortower.com/blog/tiktok-downloads-2billion

Setyawati, S. M. (2019). Dampak Integrasi E-Service Quality dan E-Satisfaction pada ERepurchase Intention Konsumen Aplikasi GO-JEK Kategori GORIDE. Performance: Jurnal Personalia, Financial, Operasional, Marketing dan Sistem Informasi, 26(2), 77-84.

Singh, M. (2020). Douyin, TikTok app in China, hits 400 million daily active users. Retrieved from https://techcrunch.com/2020/01/06/douyin-tiktok-app-inchina-hits-400-million-daily-active-users/

Singh, M. (2020). TikTok tops 2 billion downloads. Retrieved from https://techcrunch.com/2020/04/29/tiktok-tops-2-billion-downloads/

Slovin, E. (1960). Slovin's formula for sampling technique. Retrieved on February, 13, 2013.

Sreeram, A., Kesharwani, A., \& Desai, S. (2017). Factors affecting satisfaction and loyalty in online grocery shopping: an integrated model. Journal of Indian Business Research.

Su, D. N., Nguyen-Phuoc, D. Q., \& Johnson, L. W. (2019). Effects of perceived safety, involvement and perceived service quality on loyalty intention among ridesourcing passengers. Transportation, 1-25

Susilo, D. (2020). Chinese Cultural Values and Its Influence on Chinese Indonesian Entrepreneurial Culture. Asian People Journal (APJ), 3(1), 201-208.

Ting, Ong S., Ariff, Mohd. S., Zakuan, N. Sualaiman , Z \& Saman. (2016). E-Service Quality, E-Satisfaction, and E-Loyalty of Online Shoppers in Business to Consumer 
Market; Evidence from Malaysia. IOP Conf. Series: Materials Science and Engineering, doi: 10.1088/1757-899X/131/1/012012.

Wilson, N., \& Christella, R. (2019). An empirical research of factors affecting customer satisfaction: A case of the Indonesian e-commerce industry. DeReMa Jurnal Manajemen, 14(1), 21-44.

Zeglat, D., Shrafat, F., \& Al-Smadi, Z. (2016). The Impact of the E-Service Quality (E-SQ) of Online Databases on Users' Behavioural Intentions: A Perspective of Postgraduate Students. International Review of Management and Marketing, 6(1).

\section{Acknowledgement}

I would like to express my gratitude to Jacob Bills for extended discussions and valuable suggestions which have contributed greatly to the improvement of my paper. 